after he was stabbed for a period of time sufficient to have emptied the contents of one pistol at least.

This case, therefore, so far as it has any relevancy to the questions propounded by Dr. Parker, corroborates the dictum of Prof. D. H. Agnew. Very truly, Arthur Young, M.D.

Prescott, Wis., September 6, I887.

\section{COCAINE SOLUTIONS.}

Dear Sir:- When I first began the use of cocaine my plan was to have 6 or 8 ounces of a 4 per cent. solution prepared and keep it in my office, applying when necessary, until it was exhausted. I soon began to notice that at times its effect would be perfect, at other times seriously disappointing. On one occasion a patient came in for the introduction of a bougie. I injected a small quantity of the solution (which was the last of my bottle) into the urethra, retaining it some minutes, and then carefully introduced the instrument. He complained of great pain, feeling no relief from the cocaine. Two days later he returned for the same operation. In the meantime my bottle had been replenished with a fresh solution, which I injected as before, when I introduced the instrument, without pain, the patient expressing himself as not feeling it at all. I began to reflect. Why should cocaine fail at one time and succeed at another? I could see no difference in the two operations except one was with a fresh solution, the other perhaps ten days old. After this, in order to test the matter, I made a number of experiments on different cases, and was so thoroughly satisfied that I no longer keep the solution on hand, but instead the crystal muriate of cocaine, and prepare my solutions for each case; often without making an exact per cent., but simply mixing with a little water without weighing.

The results of these experiments may be summed up as follows:

I. Solutions of cocaine, even though admixed with boracic acid, gradually lose their anæesthetic powers.

2. Freshly made solutions, applied immediately, will never fail to give the most satisfactory results.

3. When freshly prepared, much weaker solutions will be needed than when kept on hand. A 2 per cent. strength is as effectual (when fresh) as a 4 per cent. two or three weeks old.

4. Fresh solutions are not productive of destructive inflammation to the eye, as has been attributed by some to older solutions.

It would probably be well to state, in conclusion, that in these experiments, its use has been chiefly confined to the male urethra. I always increase the strength of the solution in proportion to the pain to be produced. If a sensitive stricture is to be cut I use a strength of from ro to 20 per cent.; if an examination is to be made or a bougie introduced a 2 to 4 per cent. answers every purpose.

Nashville, Tenn., August 29, 1887 .

\section{NEW INSTRUMENTS.}

\section{APPARATUS FOR GASEOUS INJECTIONS. BY M. E. CONNELL, M.D., PHYSICIAN TO THE MILWAUKEE COUNTY HOSPITAL.}

This apparatus does away with the gas reservoir or rubber bag. It can be extemporized very quickly and cheaply by any physician possessed of two fruit jars, a small piece of rubber tubing, a hard rubber cock and a glass funnel. I prefer it to the original apparatus. To physicians remote from instrument shops it may prove useful.

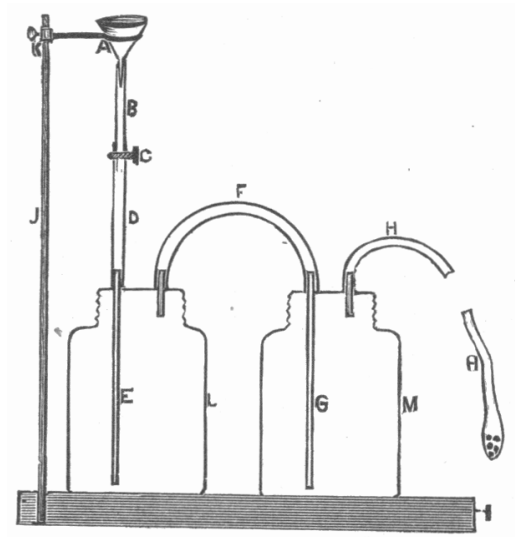

Solutign $X$-is composed of

Sulphuric acid c. p............... 7 ozs.

Water $\ldots \ldots \ldots \ldots \ldots \ldots \ldots \ldots \ldots \ldots \ldots, 2$ pts.

Solution $Y$-is composed of

Sodium bicarbonate............... I oz.

Water $. . \ldots \ldots \ldots \ldots \ldots \ldots \ldots \ldots \ldots \ldots, 4$ ozs.

Solution $Z$ - is composed of

Calcium sulphide. ............... 5 grs.

Sodium chloride. . . . . . . . . . . .

Water .......................... 22 ozs.

Two ounces $(2 \mathrm{ozs})$ of sol. $\mathrm{x}$ is allowed to drop slowly (through A) into sol. y (in L), when carbonic acid gas is generated, which passes through sol. $z$ (in $M$ ), and in combination with sulphuretted hydrogen is conveyed to the rectum through the tube $H$.

\section{BOOK REVIEWS.}

Leitfaden ZUR Antiseptischen WundbehandLUNG, mit Rücksicht auf ihren gegenwartigen Standpunkt. Von Geheimrate voN Nussbaum in München. Fünfte, gänzlich umgearbeitete Auflage. 8vo., pp. xx, 308 . Stuttgart: Verlag von Ferdinand Enke. I 887 .

Guide to the Antiseptic Treatment of Wounds. By Geheimrath von Nussbaum. Fifth, completely revised edition. Stuttgart : Ferdinand Enke. I887. Chicago: Koelling, Klappenbach \& Kenkel.

Our readers will remember that in a very recent letter Dr. Senn said that this book had done "more towards the general adoption of antiseptic principles in the treatment of wounds than all the rest of the German literature combined." That it is appreciated outside of Germany is proved by the fact that 